\title{
Socioeconomic Determinants of Mangrove Exploitation and Seagrass Degradation in Zanzibar: Implications for Sustainable Development
}

\author{
Amina A. Nchimbi $\mathbb{D}^{1,2}$ and Liberatus D. Lyimo $\mathbb{D}^{1}$ \\ ${ }^{1}$ School of Biological Sciences, University of Dodoma, P.O. Box 338, Dodoma, Tanzania \\ ${ }^{2}$ Institute of Marine Sciences, University of Dar es Salaam, P.O. Box 668, Zanzibar, Tanzania \\ Correspondence should be addressed to Amina A. Nchimbi; asiyaanchimbi@gmail.com
}

Received 19 September 2018; Revised 17 February 2019; Accepted 11 March 2019; Published 2 May 2019

Academic Editor: Horst Felbeck

Copyright (c) 2019 Amina A. Nchimbi and Liberatus D. Lyimo. This is an open access article distributed under the Creative Commons Attribution License, which permits unrestricted use, distribution, and reproduction in any medium, provided the original work is properly cited.

\begin{abstract}
The concept of "sustainability" has become the current answer to absolving the world of its environmental and economic crises in the 21st century. This paper analyses seven socioeconomic factors (age of household head, household average annual income, marital status of household head, gender of household head, household size, education level of household head, and period of residence of household head) influencing extreme degradation of seagrass and exploitation of mangrove resources in Zanzibar, Tanzania. To accomplish this, Participatory Rural Appraisal approaches and household questionnaire survey were used to obtain information on primary data. Multiple regression analysis and descriptive statistics were used to analyze quantitative data while content analysis was used to analyse qualitative data. The findings revealed that all the socioeconomic variables tested were statistically significant $(\mathrm{P}<0.05)$ and had an influence on the exploitation of mangrove and degradation of seagrass except gender of the household $(\mathrm{P}=0.88)$ and household annual average income $(\mathrm{P}=0.655)$, respectively. In addition, statistical analysis revealed that there was significant difference in the mangrove status between the sites $\left(\mathrm{p}=0.0001, \chi^{2}=27.27\right)$ with more exploitation at Charawe compared to Kibele village, whereas no significant differences were revealed in the status of seagrass between the two sites $\left(\mathrm{p}=0.2693, \chi^{2}=1.2202\right)$. On one hand, the findings revealed that at Kibele and Charawe $60 \%$ and $50 \%$ practice gleaning, $40 \%$ and $55 \%$ are engaged in seaweed farming, and $60 \%$ and $70 \%$ collect bait from seagrass meadows, respectively. All these activities had direct influence on seagrass status. On the other hand, the finding revealed that livelihood needs, population growth, level of education, and lack of alternative source of income are the key drivers to exploitation of coastal natural resources especially mangrove and seagrasses. To ensure sustainable exploitation of coastal resources alternative livelihood activities such as farmed fish, small/petty business, and agriculture activities that are profitable and easy to manage should be introduced to the local coastal community to enhance active participation in conserving resources and improving their livelihood.
\end{abstract}

\section{Introduction}

Seagrass meadows and mangrove forests are crucial not only as unique ecosystems with their own inherent qualities, but also for the support they provide to other biologically diverse ecosystems. The coastal marine vegetation are the vital components of the subsistence livelihood systems of the coastal community as they offer various social and economic values to the people [1-3]. Mangrove and seagrasses are currently recognized as hotspot in climate change mitigation because of their ability to sequester and bury substantial amount of anthropogenic carbon dioxide [48]. Seagrass alone contributes approximately $50-64 \%$ of the organic carbon sequestered annually [9] and stores large amount of carbon buried in the global ocean $[10,11]$. In addition, mangrove and seagrass meadows provide a range of ecological and socioeconomic benefits for the well-being of coastal communities $[12,13]$. Ecologically, they provide nursery for marine species, nutrient cycling, water purification, and coastal stabilization [14-16]. Important socioeconomic 
benefits include provision of wood products, sustaining subsistence and commercial fisheries, and tourism support $[10,17]$. Seagrass and mangroves provide substantial support in intertidal fisheries sector $[18,19]$. It is projected that billions of people worldwide especially in developing countries depend on coastal and marine resources for their livelihood [18]. Cochrane et al. [20] estimated that fish provide 4.3 billion people with at least $20 \%$ of their average intake of animal protein. Similarly, in WIO region it was reported that coastal communities greatly depend on fisheries resources obtained from seagrass and mangrove ecosystems [21-23]. Several studies $[22,24-26]$ reported that anthropogenic pressure caused by human activities (e.g. seaweed farming) has negatively impacted the seagrass productivity in Chwaka Bay. In addition, gleaning and bait collection have also reported to have significant impact on the healthy status of seagrass as they involve trampling and uprooting of the seagrass [22]. Geere [26] reported that $70 \%$ of the respondents declared that decrease in seagrass resulted in the decrease in fish catch and $70 \%$ of respondents reported the use of dragnet, which contributed to seagrass change. Tano et al. [27] reported change in habitats from natural seagrass to nonnative farmed seaweeds.

According to Mtwana Nordlund [13] and de la TorreCastro et al. [23] majority of coastal communities are resource dependent as they rely on marine natural resource (seagrass and mangrove) for their livelihood. However, being resource dependent is risky due to reliance on particular resources for income and employment [28]. Depletion of these resources or changes in management policy pose serious threats to the resource-dependent communities both socially and economically [29]. Overexploitation of the coastal natural resources especially mangrove is common in coastal communities including that of Unguja Island [30-33]. Several studies [13, $19,23,34]$ in Zanzibar have reported on coastal and marine resource exploitation; however, the linkage between socioeconomic factors and rate of coastal and marine resources exploitation is not well captured. This paper therefore aims at analyzing the socioeconomic factors influencing exploitation of mangrove and degradation of seagrass resources in Unguja Island. The findings from this study will provide good insight for policy makers, researchers, and local communities into the sustainable management of coastal resources, especially seagrass meadows and mangrove forests. Hence, in order to promote sustainable conservation of these resources, there is a need to identify both positive and negative socioeconomic factors influencing resources utilization in a given society.

\section{Materials and Methods}

2.1. Description of the Study Area. The study was conducted in two coastal communities in Unguja Island, Zanzibar, Tanzania. The sites were chosen based on the extent of mangrove and seagrass coverage, which are located in different major bays in Unguja Island. These were Kibele and Charawe (Chwaka Bay) (Figure 1). These sites offer prime opportunities for studying socioeconomic issues regarding mangroves and seagrass resources, because the presence of both mangroves and seagrass resources acts as the main source of income to the majority of community members in the area.

Kibele is a coastal village within the 'Shehia' of Tunguu located in the Central District $\left(6^{\circ} 13^{\prime} \mathrm{S}, 39^{\circ} 19^{\prime} \mathrm{E}\right)$. Tunguu 'Shehia' is located about $16 \mathrm{~km}$ from Zanzibar Town, and, according to 'Shehia' population census of 2013, it has a population of 3246 [35]. The main economic activities conducted in this area include fishing, gleaning of bivalves, small-scale agriculture, and other low-scale businesses.

Charawe 'Shehia' is located in the Central District $\left(6^{\circ} 11^{\prime} \mathrm{S}\right.$, $39^{\circ} 26^{\prime} \mathrm{E}$ ) and has a population of 954 [35] (Tanzania National Bureau of Statistics, 2013). The main livelihood and economic activities conducted in this area are fishing, tourism, harvesting of mangroves, other forest products, and other low-scale businesses.

2.2. Design. Participatory Rural Appraisal approach was applied to solicit information on general community knowledge and perception on coastal resource exploitation and the impacts of resource exploitation. Based on the identified indicators semistructured and open interviews were instituted to a gender balanced set of respondents randomly selected in the study areas; in each village 30 respondents were interviewed. Qualitative content analysis was employed to determine the interrelationship between coastal resources and community activities (social- ecological system). This approach helps us to identify drivers for exploitation, exploitation pressure, coastal resource status, impact, and response to exploitation $[36,37]$. Three focus group discussions (local mangrove management committee, local fisheries management committee, and coastal/marine resource users, e.g., bait collectors, seaweed farmers, and gleaners) were conducted in each study site. Focused group discussions were used to triangulate information collected through interviews with a view to produce generalizations that represent the coastal resource conservation knowledge existing in the community.

Timeline analysis was carried out during focus group discussion to solicit information on the status of mangroves and seagrass over time and the reasons for the changes. Moreover, wealth-ranking exercise was carried out to correlate the wealth status of community members with the level of resource utilization in the study areas. From the collected data, frequencies and descriptive statistics were carried out. Moreover, Chi-square $\left(\chi^{2}\right)$ test was performed to investigate the relationship between the status of mangrove and seagrass resources and the study area. In addition, multiple regression analysis [38] was carried out to determine the effect of socioeconomic factors (independent variables) influencing exploitation of mangroves and seagrass resources (fixed factors) in the study sites.

The explicit form of the model is presented as $\mathrm{Yi}=\alpha_{0}$ $+\beta_{1} \mathrm{X}_{1}+\beta_{2} \mathrm{X}_{2}+\ldots \beta_{7} \mathrm{X}_{7}+\mathrm{e}_{\mathrm{i}}$

where

$\mathrm{Yi}=$ dependent variables (number of extracted resources from mangrove forest and seagrass bed) 
TABLE 1: Socioeconomic characteristics of households in the study sites $(n=60)$.

\begin{tabular}{|c|c|c|c|c|}
\hline Particulars & Category & Charawe (\%) & Kibele (\%) & Average (\%) \\
\hline \multirow{2}{*}{ Gender of household head } & Males & 67 & 83 & 75 \\
\hline & Females & 33 & 17 & 25 \\
\hline \multirow{3}{*}{ Marital status } & Married & 82 & 57 & 70 \\
\hline & Divorced & 12 & 25 & 19 \\
\hline & Widowed & 6 & 18 & 12 \\
\hline \multirow{6}{*}{ Age } & 5-25 (years) & 12 & 6 & 9 \\
\hline & 26-30 (years) & 50 & 70 & 60 \\
\hline & 31- 45 (years) & 85 & 90 & 88 \\
\hline & $46-50$ (years) & 30 & 50 & 40 \\
\hline & $51-60$ (years) & 25 & 30 & 28 \\
\hline & $>61$ (years) & 3 & 4 & 4 \\
\hline \multirow{7}{*}{ Education } & No education & 23 & 13 & 18 \\
\hline & Informal education & 13 & 16 & 15 \\
\hline & Incomplete primary & 17 & 26 & 21 \\
\hline & Complete primary & 30 & 40 & 35 \\
\hline & Incomplete secondary & 14 & 40 & 27 \\
\hline & Complete secondary & 10 & 2 & 6 \\
\hline & Tertiary level & 16 & 6 & 11 \\
\hline \multirow{9}{*}{ Occupation } & Civil servants & 13 & 10 & 12 \\
\hline & Small businesses & 13 & 20 & 17 \\
\hline & Farming & 4 & 17 & 10 \\
\hline & Mangrove harvesting & 64 & 0 & 32 \\
\hline & Fishing & 6 & 17 & 11 \\
\hline & Seaweed farming & 55 & 40 & 48 \\
\hline & Casual labor & 0 & 17 & 8 \\
\hline & Gleaning & 50 & 60 & 55 \\
\hline & Bait collection & 70 & 60 & 65 \\
\hline \multirow{3}{*}{ Household size } & 4-6 persons & 30 & 23 & 26 \\
\hline & 7-9 persons & 47 & 45 & 46 \\
\hline & $10-12$ persons & 23 & 32 & 28 \\
\hline \multirow{3}{*}{ Monthly income } & $<232$ USD & 33 & 33 & 33 \\
\hline & (232- 465) USD & 53 & 50 & 52 \\
\hline & $>2,325 \mathrm{USD}$ & 17 & 13 & 15 \\
\hline
\end{tabular}

$\mathrm{X}_{1}$ to $\mathrm{X}_{\mathrm{n}}=$ independent variables, which were seven as follows:

$\mathrm{X}_{1}=$ age of household head

$\mathrm{X}_{2}=$ household average income

$\mathrm{X}_{3}=$ marital status of household head

$\mathrm{X}_{4}=$ gender of household head

$\mathrm{X}_{5}=$ household size

$\mathrm{X}_{6}=$ education level of household head

$\mathrm{X}_{7}=$ period of residence of the household head.

$\alpha_{0}$ is the Y-intercept while $\beta_{1} \beta_{2} \ldots \ldots \beta_{7}$ are the regression coefficients that were estimated while $\mathrm{e}_{\mathrm{i}}$ is the error term.

\section{Results}

3.1. Socioeconomic Characteristics of the Households. Socioeconomic characteristics are an economic and sociological combination of total measure of a person and economic and social position relative to others, based on their gender of household head, marital status, household size, education level, household monthly income, age, and period of residence. These characteristics are presented in Table 1. Overall results show that majority (75\%) of the household heads were males and only $25 \%$ of the household heads were female in the study sites. In case of marital status, majority (70\%) of household heads were married. The distribution of their household size revealed that $26 \%$ of the respondents had family size of 4-6 persons, $46 \%$ had family size of 7-9 persons, and $28 \%$ had family size of more than 10 persons. The average household size was estimated to be nine, an indication of a relatively larger household size. On their education level, majority $(21 \%)$ of the household heads had not completed primary education and $18 \%$ had no education level at all, only $11 \%$ of the household heads had attained tertiary level of education, and $15 \%$ had informal level of education. Furthermore, the 
TABLE 2: Timeline analysis of mangrove forest status at Charawe and Kibele (key informant: village leader and elders).

\begin{tabular}{|c|c|c|c|c|c|}
\hline Period & $\begin{array}{l}\text { Status of } \\
\text { mangrove } \\
\text { forest in Kibele }\end{array}$ & $\begin{array}{l}\text { Status of mangrove } \\
\text { forest in Charawe }\end{array}$ & Reasons for Kibele & Reasons for Charawe & Source \\
\hline 1964-1972 & $\begin{array}{l}\text { Dense } \\
\text { mangrove } \\
\text { forest cover, } \\
\text { tall mangrove } \\
\text { trees species } \\
\text { present. Status } \\
\text { was very good }\end{array}$ & $\begin{array}{l}\text { Dense mangrove } \\
\text { forest cover, tall } \\
\text { mangrove trees of } \\
\text { species present and } \\
\text { status was very } \\
\text { good }\end{array}$ & $\begin{array}{l}\text { Demand for mangrove was } \\
\text { small, small population } \\
\text { size, only men were } \\
\text { involved in mangrove } \\
\text { activities and conservation } \\
\text { management by } \\
\text { government officials }\end{array}$ & $\begin{array}{l}\text { Demand for mangrove was } \\
\text { small, population size was } \\
\text { small, only men were } \\
\text { involved in mangrove } \\
\text { activities, conservation was } \\
\text { under government officials } \\
\text { and use of traditional rules }\end{array}$ & Key informant \\
\hline 1990-1995 & $\begin{array}{l}\text { Decrease in } \\
\text { mangrove } \\
\text { forest cover } \\
\text { bad status }\end{array}$ & $\begin{array}{l}\text { Decrease in } \\
\text { mangrove forest } \\
\text { cover at slow rate } \\
\text { bad status }\end{array}$ & $\begin{array}{l}\text { Increase in population size, } \\
\text { increase in mangrove } \\
\text { demand, only men were } \\
\text { involved in mangrove } \\
\text { harvesting and breaching } \\
\text { the government laws }\end{array}$ & $\begin{array}{l}\text { Increase in population size, } \\
\text { increase in mangrove } \\
\text { demand, only men were } \\
\text { involved in mangrove } \\
\text { activities, breaching of } \\
\text { government laws and } \\
\text { neglecting the traditional } \\
\text { rules. }\end{array}$ & Key informant \\
\hline 1996-2000 & $\begin{array}{l}\text { Decrease in } \\
\text { mangrove } \\
\text { forest at fast } \\
\text { rate hence very } \\
\text { bad status }\end{array}$ & $\begin{array}{l}\text { Decrease in } \\
\text { mangrove forest } \\
\text { cover hence bad } \\
\text { status }\end{array}$ & $\begin{array}{l}\text { Introduction of charcoal } \\
\text { making, dye production, } \\
\text { building poles, firewood, } \\
\text { women and youth were } \\
\text { involved in mangrove } \\
\text { harvesting and use of chain } \\
\text { saw }\end{array}$ & $\begin{array}{l}\text { Increase in mangrove } \\
\text { demand, women and youth } \\
\text { were involved in mangrove } \\
\text { harvesting and use of chain } \\
\text { saw. }\end{array}$ & Key informant \\
\hline 2000-to date & Good status & Very bad status & $\begin{array}{l}\text { Introduction of local } \\
\text { community mangrove } \\
\text { management committee, } \\
\text { replanting of mangrove } \\
\text { forest, burnt use of saw } \\
\text { machine, burnt charcoal } \\
\text { making, availability of } \\
\text { creditable livelihood/forest }\end{array}$ & $\begin{array}{l}\text { Rapid increase in } \\
\text { population size, lack of } \\
\text { alternative creditable } \\
\text { livelihood, poor transport } \\
\text { network system, } \\
\text { community engage in } \\
\text { mangrove charcoal making } \\
\text { activities. }\end{array}$ & Present study \\
\hline
\end{tabular}

results indicate that majority $(52 \%)$ of the households had an average annual income ranging from 465 to 2,325 USD, while few (15\%) households earned an average annual income above 2,325 USD and most of them (17\%) were found in Charawe village. The age distribution of the household heads shows that respondents with age between 26-30 (60\%), 31$45(88 \%)$, and $46-50(40 \%)$ years constituted majority of respondents. This implies that majority of respondents were young and within the economically active age. Those with age above 61 years constituted only $4 \%$, an indication of old and less economic active age who are dependent (Table 1).

3.2. Mangrove Status in the Study Area. Mangrove exploitation showed significant difference between the two studied villages Kibele and Charawe $\left(p=0.0001, \chi^{2}=27.27\right)$. At Charawe, $49.2 \%$ of respondents revealed high mangrove exploitation as compared to the situation that existed 10 years ago due to the persisting illegal and unsustainable mangrove harvesting (Figures 2(a) and 2(b)), hence making the current status of this resource very bad (Figure 3). On the contrary, many respondents $(56 \%)$ at Kibele revealed that the status of mangroves is better as compared to the situation that existed 10 years back. Generally, the results showed that mangroves of Charawe have been significantly impacted by anthropogenic activities as compared to Kibele (Figure 3). Timeline analysis revealed significant reduction in mangrove from 1965 to date (Table 2) due to unmanageable clearing for source of energy (charcoal and firewood) (Figure 2(a)), timber (Figure 2(b)), and making fishing trap/crab cages (Figure 2(c)).

3.3. Status of Seagrass Beds. Statistical analysis revealed no significant difference on the status of seagrass between the two sites $\left(p=0.2693, \chi^{2}=1.2202\right)$. Eighty-seven percent and ninety-one percent of the respondents at Charawe and Kibele, respectively, stated that status of seagrass was good (Figure 4). Timeline analysis for seagrass (Table 3 ) is inconsistent from 1962 to date; the observed inconsistence could be due to either failure of the key informant to notice the disappearances of seagrass since it is under water or the loss that sometimes occurs without human conscious. However, direct observation depicted gleaning, seaweed farming, and uprooting of long seagrass (Enhalus acoroides and Thalassodendron ciliatum) for assisting in burning the mangroves logs during charcoal making at Charawe village (Figure 2(d)) had great contribution to seagrass loss. 
TABLE 3: Timeline analysis of seagrass status in Charawe and Kibele village since 1962 to date.

\begin{tabular}{|c|c|c|c|c|c|}
\hline Period & $\begin{array}{l}\text { Status of } \\
\text { seagrass bed in } \\
\text { Kibele }\end{array}$ & $\begin{array}{l}\text { Status of seagrass } \\
\text { bed in Charawe }\end{array}$ & Reasons for Kibele & Reasons for Charawe & Source \\
\hline 1964-1972 & Very good & Very good & $\begin{array}{l}\text { Small population size, few } \\
\text { fishermen, fishing using } \\
\text { traps by old people and } \\
\text { conservation management } \\
\text { by government officials }\end{array}$ & $\begin{array}{l}\text { Small population size, few } \\
\text { fishermen, only old people } \\
\text { fished in seagrass beds, use } \\
\text { of traps and conservation } \\
\text { by government officials }\end{array}$ & Key informant \\
\hline 1990-1995 & $\mathrm{Bad}$ & $\mathrm{Bad}$ & $\begin{array}{l}\text { Introduction of improved } \\
\text { vessels, deep water fishing, } \\
\text { drag net fishing, youth and } \\
\text { old people involved and } \\
\text { breaching the government } \\
\text { laws }\end{array}$ & $\begin{array}{l}\text { Introduction of improved } \\
\text { vessels, deep water fishing, } \\
\text { drag net fishing, youth and } \\
\text { old people involved and } \\
\text { breaching the government } \\
\text { laws }\end{array}$ & Key informant \\
\hline 1996-2000 & Good & Good & $\begin{array}{l}\text { Lack of money value of the } \\
\text { resource to the community, } \\
\text { burnt use of drag nets and } \\
\text { introduction of } \\
\text { management committee }\end{array}$ & $\begin{array}{l}\text { Lack of money value of the } \\
\text { resource to the community, } \\
\text { burnt use of drag nets and } \\
\text { introduction of } \\
\text { management committee }\end{array}$ & Key informant \\
\hline 2000-to date & Good & Good & $\begin{array}{l}\text { Controlling harvesting of } \\
\text { bivalves and availability of } \\
\text { creditable livelihood } \\
\text { Gleaning and bait } \\
\text { collection activity heavily } \\
\text { conducted }\end{array}$ & $\begin{array}{l}\text { Lack of valuable resources } \\
\text { on seagrass beds and } \\
\text { community concentrate } \\
\text { with mangrove extraction } \\
\text { Gleaning, bait collection, } \\
\text { and seaweed farming }\end{array}$ & Key informant \\
\hline
\end{tabular}

TABLE 4: Multiple regression analysis of socioeconomic factors influencing extraction of mangrove and seagrass resources in the study areas. Mangrove $\left(n=60, R^{2}=0.614\right.$ ) and seagrass $R^{2}=0.562, *=$ statistically significant at 0.05 level of significance.

\begin{tabular}{|c|c|c|c|c|}
\hline \multicolumn{5}{|c|}{ Mangrove } \\
\hline Variables & $\beta$ & Standard error & $\mathrm{t}$ & P-value \\
\hline Age of household head & 0.236 & 0.214 & 3.738 & $0.001 *$ \\
\hline Household average annual income & 0.564 & 0.000 & 10.62 & $0.001 *$ \\
\hline Marital status of household head & -0.213 & 0.175 & -3.18 & $0.002 *$ \\
\hline Gender of household head & -0.010 & 0.418 & -0.149 & 0.882 \\
\hline Household size & -0.217 & 0.056 & -3.937 & $0.001 *$ \\
\hline Education level of household head & -0.229 & 0.079 & -4.002 & $0.001 *$ \\
\hline Period of residence of household head & -0.511 & 0.009 & -7.971 & $0.001 *$ \\
\hline \multicolumn{5}{|c|}{ Seagrass } \\
\hline Age of household head & 0.168 & 0.229 & 2.502 & $0.013 *$ \\
\hline Household average annual income & 0.026 & 0.148 & 0.447 & 0.655 \\
\hline Marital status of household head & 0.166 & 0.188 & 2.327 & $0.021 *$ \\
\hline Gender of household head & 0.404 & 0.449 & 5.695 & $0.001 *$ \\
\hline Household size & -0.206 & 0.268 & -3.533 & $0.001 *$ \\
\hline Education level of household head & 0.118 & 0.085 & 1.920 & 0.057 \\
\hline Period of residence of household head & 0.387 & 0.010 & 5.633 & $0.001 *$ \\
\hline
\end{tabular}

3.4. Socioeconomic Factors Influencing Extraction of Mangrove and Seagrass Resources. The present findings revealed that all socioeconomic variables (Table 4 ) tested were statistically significant $(\mathrm{P}<0.05)$ and had an influence on the exploitation of mangrove and degradation of seagrass except gender of the household $(\mathrm{P}=0.88)$ for mangroves, household annual average income $(\mathrm{P}=0.655)$, and education of household head (0.057) for seagrass (Table 4). For example, the age of the household and household income had a significant influence on exploitation of mangrove forest with positive regression coefficients $(\beta)=0.236$ and 0.564 , respectively. Moreover, change in marital status, household size, change in education level, and period of residence of the household had a significant influence on exploitation of mangrove forest with negative regression coefficients $(\beta)=-0.213,-0.217$, 0.229 , and -0.511 , respectively, while gender of the household had no significant influence on the mangrove forest exploitation $(\mathrm{P}=0.882)$. For the case of seagrass degradation 

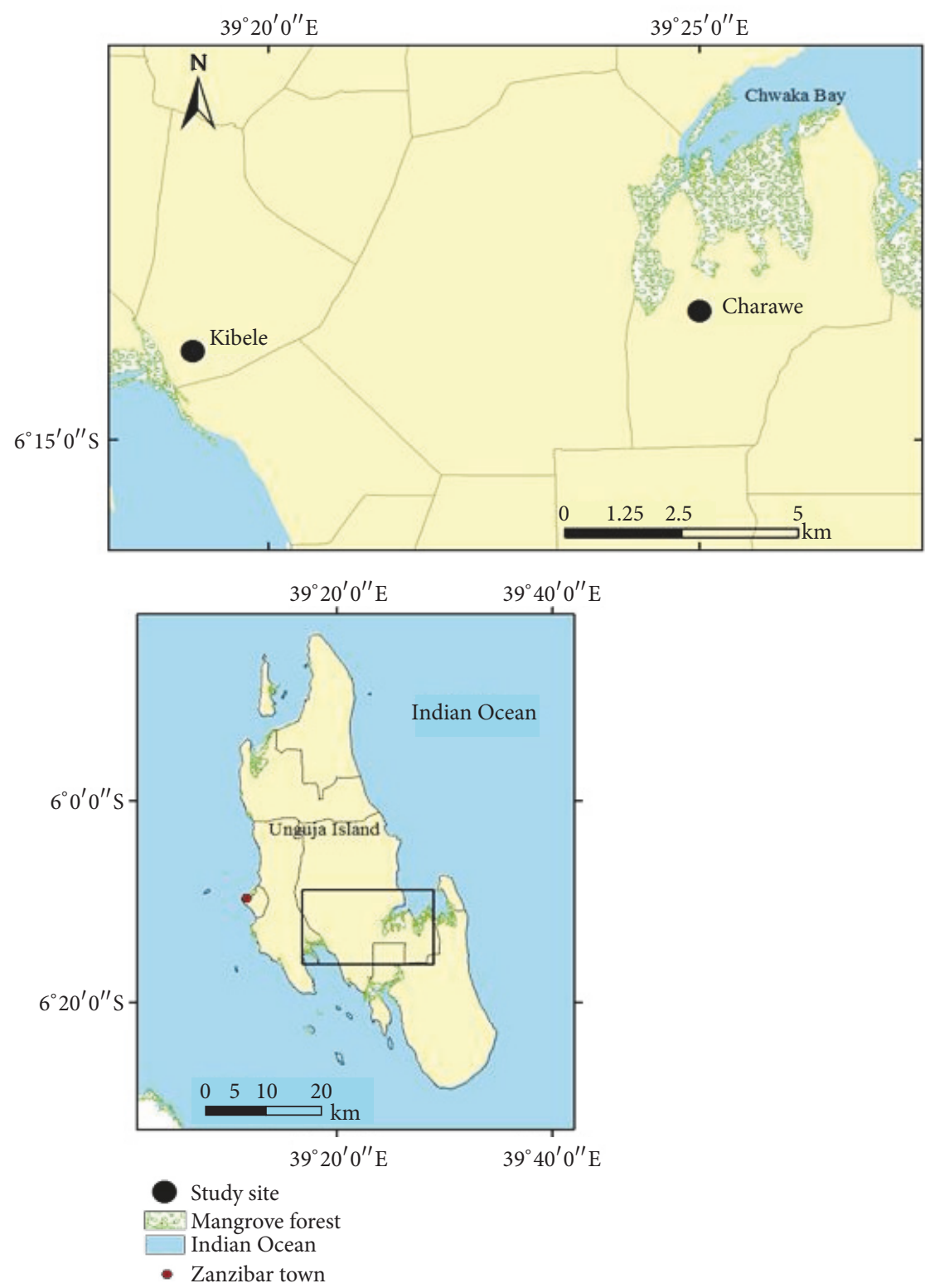

FIGURE 1: Unguja map showing the study sites (Source IMS Database).

all socioeconomic variables, including age of the household, marital status, gender of the household, education level, and period of residence of household, had significant impact on the degradation of seagrass with positive regression coefficients except household size with negative regression $(\beta)=-0.206$. Household annual average income $(\mathrm{P}=0.655)$ had no significant influence on the degradation of seagrass (Table 4).

\section{Discussion}

In all the study sites, the determinants of mangrove exploitation and seagrasses degradation were demographic change and socioeconomic characteristics. Increase in population growth has increased the demand for natural coastal resources from mangrove to seagrass. Good example is tremendous increase in demand for building poles, wood fuel, fish trap, and charcoal making (Figures 2(a), 2(b), and 2(c)) which specifically comes from mangroves [39]. Quinn et al. [37], Hussain [40], and Semesi [41] reported similar situations in three countries: Brazil, Vietnam, and Zanzibar. The findings also reveal that the increase in human activities, for example, bivalve collection, bait collection, and seaweed farming, at Kibele and Charawe village, with average percent of 55, 65, and 48 (Table 1), respectively, significantly increased pressure on seagrass degradation. Similarly, Nordlund et 


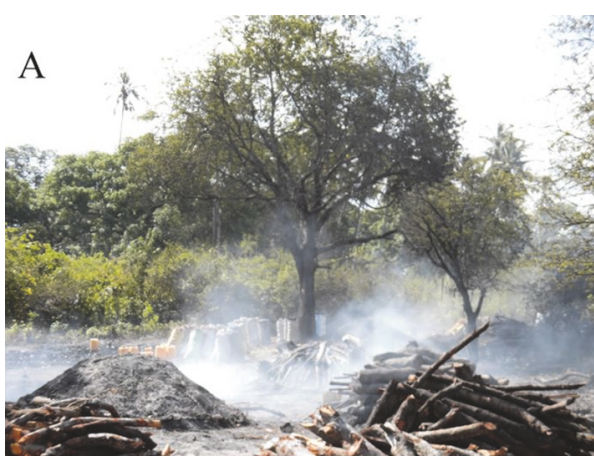

(a)

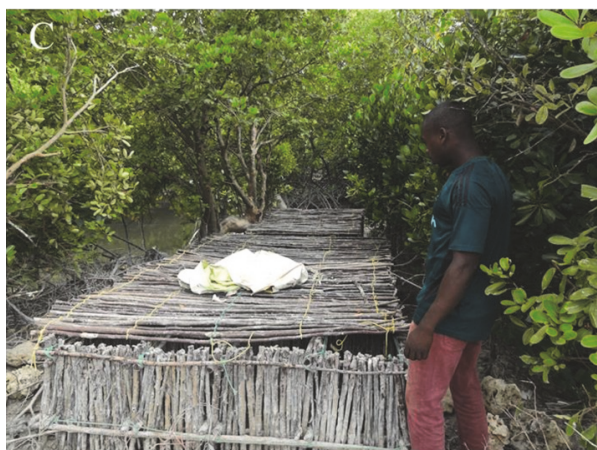

(c)

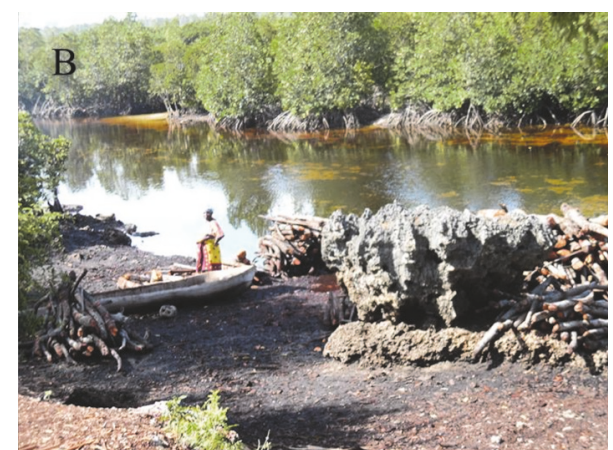

(b)

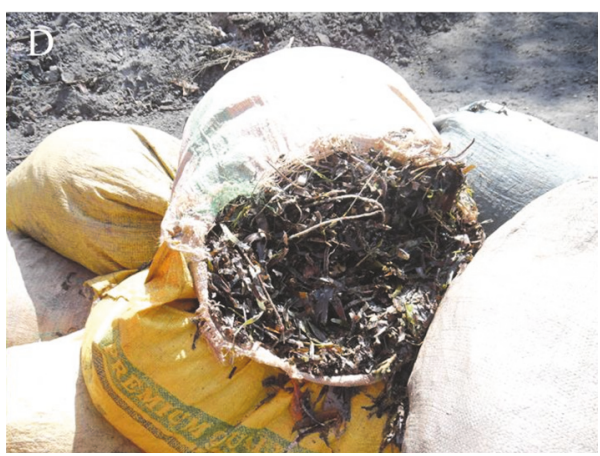

(d)

FIGURE 2: ((a) and (b)) mangrove clearing for charcoal making at Charawe village, (c) mangrove clearing for crab cage making at Kibele village, and (d) seagrass collected/parked for charcoal burning at Charawe village (photo by Amina Asiya Nchimbi).

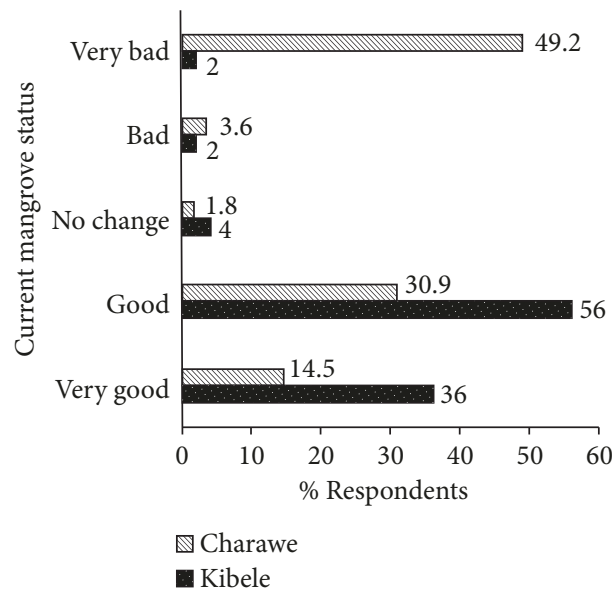

FIGURE 3: Perception on the current mangrove status in Charawe and Kibele as compared to the situation 10 years ago.

al. [19] reported the increase in gleaners, both women and children in seagrass ecosystem in Zanzibar. Moreover, assessment done by Watson et al. [42] revealed that the global catch of bivalves is approximately 121,000 tonnes per annum with a retail value of $£ 5.5$ billion. This increase comes with physical disturbance in seagrass meadows; for example, Garmendia et al. [43], Watson et al. [42], and Eckrich and Holmquist [44] reported the effect of trampling and digging

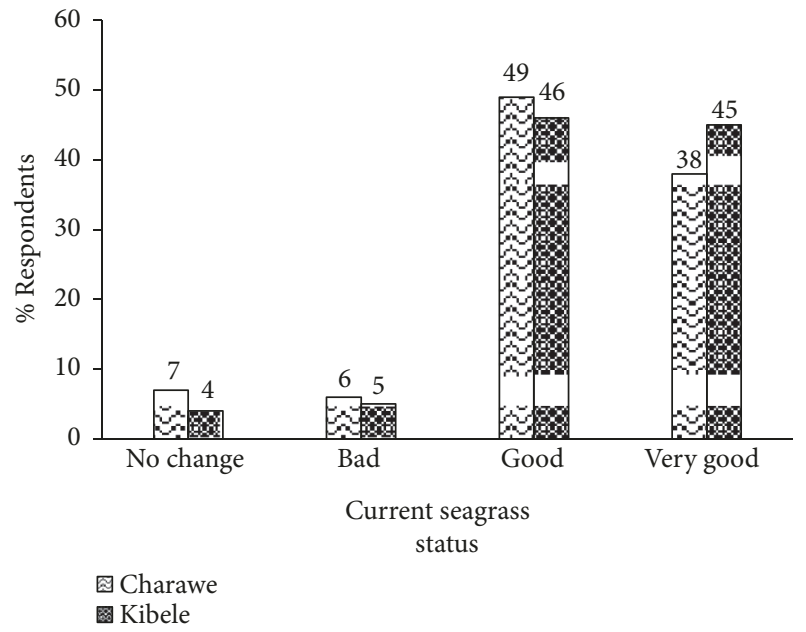

FIGURE 4: Perception on current status of seagrass beds in Charawe and Kibele as compared to the situation 10 years ago.

during bait collection in Zostera noltii (Zosteraceae) and Thalassia testudinum.

The present study revealed that substantial numbers of respondents (48\%) in all sites studied engage in seaweed farming, and they contribute unknowingly to seagrass degradation. The reports from several authors [22, 24-26] have confirmed seaweed farming in seagrass meadows having 
negative effects on seagrass characteristics including plant height, biomass, and plant density. Mangroves exploitation and seagrass degradation in the Zanzibar coastal communities are influenced by various factors and each factor reflected the reality in terms of social livelihood of the coastal communities in the study sites. The findings reveal that age of household head had significant influence on the extraction of both mangrove and seagrass resources in the study sites. Mangrove resources extracted were used for charcoal making, boat making, building poles, and fuel wood [45]. Quinn et al. [37] reported similar findings in Brazil and Vietnam, whereas the resources extracted from seagrass included bivalve and bait collection $[19,43]$ and seaweed $[22,42]$ through seaweed farming and fish by using fishnets and traps. The resources obtained from both mangrove forest and seagrass meadows were collected by economically active ages ranging from 26 to 50 years old. The resources were for substance use or selling within and outside the villages. These findings are consistent with the findings reported by Branch et al. [46] who noted that productive ages are involved in many development activities which may also be associated with degradation of natural resources.

Moreover, the results show that marital status of the household head had a significant influence on the exploitation of the mangroves resources as well as seagrass degradation. It was observed from the focus group discussions and personal observation that married household heads extracted many resources from mangrove forest and seagrass meadows in order to meet the demands of their family members (wives and children). The involvement of the family members such as the elder sons in mangrove extraction, wives, elder daughters, and young children in seagrass resource extraction also increased the pressure on these resources. This was not the case in single household heads because this group has less demand when it came to seagrass and mangrove resources because they were living alone and had no family members of their own to take care of. Similarly, Nussbaum [47] and Shackleton et al. [48] reported that married individuals had significant influence on exploitation of natural resources in a given area.

The results showed that household size had significant influence on the extraction of both seagrass resources and mangrove forests. Increase in household size increased the number of people who were engaged in the extraction of seagrass and mangrove resources in the study sites. This therefore led to the decrease in the resources obtained from the mangrove forest and seagrass meadows as a result of increase in demand for these resources. This was observed from personal observation where there was increase in the number of gleaners, net and trap fishers, seaweed farmers, charcoal making, and building poles collectors. This increase has led to the decrease in the resources obtained from seagrass and mangrove forest, respectively, through unsustainable harvesting. Related findings have been confirmed by Jiddawi and Öhman [49] and Mtwana Nordlund [13] who reported that household size with a lot of women is predominantly involved in the invertebrate harvesting, which is commonly conducted on rocky shores, in mangroves and seagrass meadows, in unsustainable manner due to lack of formal management.

Educational level of the household head had significant influence on the extraction of mangrove resources and seagrass resources. The negative regression coefficient on the mangrove resource extraction implied that increase in education level of the household head leads to decrease in the extraction of the mangrove resources. Thirty-five percent of the respondents have received at least primary education (Table 1) and this might have been attributed to development and engaging of community members to various livelihood activities such as owning small shops, food vending, and casual labor, therefore reducing pressure on the mangrove resource extraction. This study is in line with earlier findings of Nussbaum [47] and Shackleton et al. [48] who found out that the more education one attains helps one better in the management of natural resources. On the other hand, seagrass resource extraction has increased with the increase in the level of education. This might be due to the fact that since the majority of the coastal communities in the study site have attained only primary level education, it becomes very hard for this majority group to secure a white-collar job, hence ending up employing themselves in the smallscale fisheries (SSF) within the seagrass meadows, therefore promoting unsustainable extraction of seagrass resources.

The results also revealed that household average annual income had significant influence on the extraction of mangrove resources. The increasing standards of living and low level of education of the majority of the coastal communities in the study sites have limited them to secure government and private employment opportunities. This situation forces the local coastal community to rely on mangrove resources as an alternative source of income generation through selling of building poles, making charcoal, fuel wood, fish traps, and poles for boat making. Similar findings were also reported by Dahdouh-Guebas et al. [50] and Jin et al. [51] in Kenya and China, respectively. Despite the awareness on the importance of marine natural resources, particularly mangrove, their exploitation is still alarming due to economic dependency and lack of alternative source of energy for their daily use $[52,53]$ imposing significant pressure on the mangrove forest.

Households headed by males had significant influence on seagrass resource extraction. These household heads had the ability of conducting fishing activities within and outside the villages on seagrass meadows found in shallow waters and deep waters using traps and fishing nets, unlike their femaleheaded counterparts who engage themselves in bivalve collection and seaweed farming. This was noted from participant observation and focus group discussions conducted in the study sites. The different roles performed by different genders in exploitation of resources can in one way or another impact the conservation of a given resource. This finding is in connection with other studies conducted by Gadio and Rakowski [54], Crus-Torres [55], and Mtwana Nordlund [13] who noted that some roles of gender in the exploitation of natural resource may undermine ecosystem sustainability. The results further show that period of residence of the household head in a given village had significant contribution to the extraction rate of the mangroves and seagrass resources. The 
less the time/period people stay in a given area, the less their families grow in size; thus less mangrove resources will be demanded from the mangrove forest, and vice versa. Similar observations were reported by Giliba et al. [56] and Kajembe [57] which indicated that people who stay longer in a given area with resource availability are more likely to exploit more of those resources than those who stay for a short duration. Timeline analysis revealed continued decrease in mangrove (Table 2) due to active interaction between the coastal ocean and community surrounding the ocean. The most important drivers for coastal resources (mangroves and seagrass) exploitation are the demographic characteristics of the coastal community including population growth, limited arable land, and development of tourism industry in Zanzibar. Despite the existence of laws and bylaws governing the mangrove conservation and sustainable exploitation, there is a need for enforcement of these laws to avoid unsustainable mangroves exploitation. Moreover, we suggest the establishment and introduction of laws and bylaws to govern seagrass conservation and utilization by the local management committees and local coastal communities.

To ensure sustainable exploitation of coastal resources alternative livelihood activities such as farmed fish, small/petty business, and agriculture activities that are profitable and easy to manage should be introduced to the coastal/marine resource dependents.

\section{Data Availability}

Research data are available when needed.

\section{Conflicts of Interest}

The authors declare that they have no conflicts of interest.

\section{Acknowledgments}

The authors extend sincere acknowledgment to the Coastal Ecosystem Services in East Africa (CESEA) for funding this project. We also extend our thanks to Mangrove Committee Members and local authorities in the study sites for allowing this work to be conducted in their areas.

\section{References}

[1] C. M. Duarte and C. L. Chiscano, "Seagrass biomass and production: a reassessment," Aquatic Botany, vol. 65, no. 1-4, pp. 159-174, 1999.

[2] L. Cullen-Unsworth and R. Unsworth, "Seagrass meadows, ecosystem services, and sustainability," Environment International, vol. 55, no. 3, pp. 14-28, 2013.

[3] R. Costanza, R. de Groot, P. Sutton et al., "Changes in the global value of ecosystem services," Global Environmental Change, vol. 26, no. 1, pp. 152-158, 2014.

[4] E. McLeod, G. L. Chmura, S. Bouillon et al., "A blueprint for blue carbon: toward an improved understanding of the role of vegetated coastal habitats in sequestering CO2," Frontiers in Ecology and the Environment, vol. 9, no. 10, pp. 552-560, 2011.
[5] J. W. Fourqurean, C. M. Duarte, H. Kennedy et al., "Seagrass ecosystems as a globally significant carbon stock," Nature Geoscience, vol. 5, no. 7, pp. 505-509, 2012.

[6] K. J. McGlathery, L. K. Reynolds, L. W. Cole, R. J. Orth, S. R. Marion, and A. Schwarzschild, "Recovery trajectories during state change from bare sediment to eelgrass dominance," Marine Ecology Progress Series, vol. 448, pp. 209-221, 2012.

[7] P. S. Lavery, M.-Á. Mateo, O. Serrano, and M. Rozaimi, "Variability in the carbon storage of seagrass habitats and its implications for global estimates of blue carbon ecosystem service," PLoS ONE, vol. 8, Article ID e73748, 2013.

[8] L. M. Schile, J. B. Kauffman, S. Crooks, J. W. Fourqurean, J. Glavan, and J. P. Megonigal, "Limits on carbon sequestration in arid blue carbon ecosystems," Ecological Applications, vol. 27, no. 3, pp. 859-874, 2017.

[9] C. M. Duarte, I. J. Losada, I. E. Hendriks, I. Mazarrasa, and N. Marbà, "The role of coastal plant communities for climate change mitigation and adaptation," Nature Climate Change, vol. 3, pp. 961-968, 2013.

[10] C. M. Duarte, J. J. Middelburg, and N. F. Caraco, "Major role of marine vegetation on the oceanic carbon cycle," Biogeosciences, vol. 2, no. 1, pp. 1-8, 2005.

[11] H. Kennedy, J. Beggins, C. M. Duarte et al., "Seagrass sediments as a global carbon sink: isotopic constraints," Global Biogeochemical Cycles, vol. 24, no. 4, 2010.

[12] M. Nurse and J. Kabamba, "Defining institutions for collaborative mangrove management: a case study from Tanga," in Tanzania Analytical Issues in Participatory Natural Resource Management, pp. 53-72, Springer, 2001.

[13] L. Mtwana Nordlund, People and the Intertidal: Human Induced Changes, Biodiversity Loss, Livelihood Implications and Management in the Western Indian Ocean, 2012.

[14] M. Björk, F. Short, E. Mcleod, and S. Beer, Managing Seagrasses for Resilience to Climate Change, IUCN, 2008.

[15] E. B. Barbier, S. D. Hacker, C. Kennedy, E. W. Koch, A. C. Stier, and B. R. Silliman, "The value of estuarine and coastal ecosystem services," Ecological Monographs, vol. 81, no. 2, pp. 169-193, 2011.

[16] T. van der Heide, J. S. Eklöf, E. H. van Nes et al., "Ecosystem engineering by seagrasses interacts with grazing to shape an intertidal landscape," PLoS ONE, vol. 7, no. 8, Article ID e42060, 2012.

[17] L. Omodei Zorini, C. Contini, N. Jiddawi, J. Ochiewo, J. Shunula, and S. Cannicci, "Participatory appraisal for potential community-based mangrove management in East Africa," Wetlands Ecology and Management, vol. 12, no. 2, pp. 87-102, 2004.

[18] S. Schmidt, B. Neumann, Y. Waweru, C. Durussel, S. Unger, and M. Visbeck, SDG14 Conserve and Sustainably Use the Oceans, Seas and Marine Resources for Sustainable Development, International Council for Science, 2017.

[19] L. M. Nordlund, R. K. F. Unsworth, M. Gullström, and L. C. Cullen-Unsworth, "Global significance of seagrass fishery activity," Fish and Fisheries, vol. 19, no. 3, pp. 399-412, 2018.

[20] K. Cochrane, C. De Young, D. Soto, and T. Bahri, "Climate change implications for fisheries and aquaculture," Tech. Rep. 530, FAO Fisheries and Aquaculture, 2009.

[21] M. Gullström, M. De La Torre Castro, S. O. Bandeira et al., "Seagrass ecosystems in the Western Indian Ocean," AMBIO, vol. 31, no. 7-8, pp. 588-596, 2002.

[22] M. De La Torre-Castro and P. Rönnbäck, "Links between humans and seagrasses - An example from tropical East Africa," Ocean \& Coastal Management, vol. 47, no. 7-8, pp. 361-387, 2004. 
[23] M. De la Torre-Castro, G. Di Carlo, and N. S. Jiddawi, "Seagrass importance for a small-scale fishery in the tropics: the need for seascape management," Marine Pollution Bulletin, vol. 83, no. 2, pp. 398-407, 2014.

[24] J. S. Eklöf, M. De La Torre Castro, L. Adelsköld, N. S. Jiddawi, and N. Kautsky, "Differences in macrofaunal and seagrass assemblages in seagrass beds with and without seaweed farms," Estuarine, Coastal and Shelf Science, vol. 63, no. 3, pp. 385-396, 2005.

[25] T. J. Lyimo, E. F. Mvungi, C. Lugomela, and M. Björk, "Seagrass biomass and productivity in seaweed and non-seaweed farming areas in the East Coast of Zanzibar," Western Indian Ocean Journal of Marine Science, vol. 5, pp. 141-152, 2006.

[26] D. Geere, Adaption to Climate-Related Changes in Seagrass Ecosystems in Chwaka Bay (Zanzibar), Göteborgs University, Sweden, 2014.

[27] S. A. Tano, C. Halling, E. Lind, A. Buriyo, and S. A. Wikström, "Extensive spread of farmed seaweeds causes a shift from native to non-native haplotypes in natural seaweed beds," Marine Biology, vol. 162, no. 10, pp. 1983-1992, 2015.

[28] C. Bailey and C. Pomeroy, "Resource dependency and development options in coastal Southeast Asia," Society \& Natural Resources, vol. 9, no. 2, pp. 191-199, 1996.

[29] W. R. Freudenburg, "Addictive economies: extractive industries and vulnerable localities in a changing world economy," Rural Sociology, vol. 57, no. 3, pp. 305-332, 1992.

[30] S. Nasser, Socio-Economic and Ecological Study of Mangrove Forest Management in Zanzibar, Tanzania. A case from Chwaka Bay, 1994.

[31] T. Masoud and R. Wild, "Sustainable use and conservation management of mangroves in Zanzibar, Tanzania," in Mangrove Management and Conservation: Present and Future, pp. 280296, United Nations University Press, New York, NY, USA, 2004.

[32] SONARECO, The Zanzibar Mangroves Socio-economic Survey, Department of Commercial Crops, Fruits and Forestry, Zanzibar, 2008.

[33] H. M. Hamad, I. Mchenga, and M. I. Hamisi, "Status of exploitation and regeneration of mangrove forests in Pemba Island, Tanzania," Global Journal of Bio-Science and Biotechnology, vol. 3, pp. 12-18, 2014.

[34] N. Hedberg, K. von Schreeb, S. Charisiadou, N. S. Jiddawi, M. Tedengren, and L. M. Nordlund, "Habitat preference for seaweed farming - A case study from Zanzibar, Tanzania," Ocean \& Coastal Management, vol. 154, pp. 186-195, 2018.

[35] NBoS, Population and Housing Census, National Bureau of Statistics (NBS), Dar es Salaam, Tanzania, 2013.

[36] S. R. Gari, A. Newton, and J. D. Icely, "A review of the application and evolution of the DPSIR framework with an emphasis on coastal social-ecological systems," Ocean \& Coastal Management, vol. 103, pp. 63-77, 2015.

[37] C. H. Quinn, L. C. Stringer, R. J. Berman et al., "Unpacking changes in mangrove social-ecological systems: lessons from Brazil, Zanzibar, and Vietnam," Resources, vol. 6, no. 14, 2017.

[38] J. F. Hair, C. M. Ringle, and M. Sarstedt, "Partial least squares structural equation modeling: rigorous applications, better results and higher acceptance," Long Range Planning, vol. 46, no. 1-2, pp. 1-12, 2013.

[39] M. Ngoile and J. Shunula, "Status and exploitation of the mangrove and associated fishery resources the ecology of mangrove and related ecosystems," in Proceedings of the International
Symposium held at Mombasa, Kenya, 24-30 September 1990, pp. 229-234, Springer Science \& Business Media, 2013.

[40] M. Z. Hussain, "Silviculture of mangroves," Unasylva, vol. 181, pp. 36-42, 1995.

[41] A. K. Semesi, "Mangrove management and utilization in Eastern Africa," AMBIO, vol. 27, no. 8, pp. 620-626, 1998.

[42] G. J. Watson, J. M. Murray, M. Schaefer, A. Bonner, and M. Gillingham, "Assessing the impacts of bait collection on inter-tidal sediment and the associated macrofaunal and bird communities: The importance of appropriate spatial scales," Marine Environmental Research, vol. 130, pp. 122-133, 2017.

[43] J. M. Garmendia, M. Valle, Á. Borja et al., "Effect of trampling and digging from shellfishing on Zostera noltei (Zosteraceae) intertidal seagrass beds," Scientia Marina, vol. 81, no. 1, pp. 121128, 2017.

[44] C. E. Eckrich and J. G. Holmquist, "Trampling in a seagrass assemblage: direct effects, response of associated fauna, and the role of substrate characteristics," Marine Ecology Progress Series, vol. 201, pp. 199-209, 2000.

[45] M. A. K. Ngoile and J. P. Shunula, "Status and exploitation of the mangrove and associated fishery resources in Zanzibar," Hydrobiologia, vol. 247, no. 1-3, pp. 229-234, 1992.

[46] G. M. Branch, J. May, B. Roberts, E. Russell, and B. M. Clark, "Case studies on the socio-economic characteristics and lifestyles of subsistence and informal fishers in South Africa," South African Journal of Marine Science, no. 24, pp. 439-462, 2002.

[47] M. Nussbaum, "Women's capabilities and social justice," Journal of Human Development, vol. 1, no. 2, pp. 219-247, 2000.

[48] S. Shackleton, C. O. Delang, and A. Angelsen, "From subsistence to safety nets and cash income: exploring the diverse values of non-timber forest products for livelihoods and poverty alleviation," in Non-Timber Forest Products in the Global Context, pp. 55-81, Springer, 2011.

[49] N. S. Jiddawi and M. C. Öhman, "Marine fisheries in Tanzania," AMBIO, vol. 31, no. 7-8, pp. 518-527, 2002.

[50] F. Dahdouh-Guebas, C. Mathenge, J. G. Kairo, and N. Koedam, "Utilization of mangrove wood products around Mida Creek "Kenya" amongst subsistence and commercial users," Economic Botany, vol. 54, no. 4, pp. 513-527, 2000.

[51] J. Jin, Z. Wang, S. Ran, and C. Yun, "Study on coastal resource evaluation theories and methods," in Proceedings of the International Conference on Estuaries and Coasts, pp. 9-11, Citeseer, 2003.

[52] P. J. Ferraro and A. Kiss, Direct Payments to Conserve Biodiversity, American Association for the Advancement of Science, 2002.

[53] M. M. Mangora, "Poverty and institutional management standoff: a restoration and conservation dilemma for mangrove forests of Tanzania," Wetlands Ecology and Management, vol. 19, no. 6, pp. 533-543, 2011.

[54] C. M. Gadio and C. A. Rakowski, Women's Changing Roles and Status in Thieudeme, Senegal: The Impact of Local and Global Factors, Michigan State University, 1999.

[55] M. L. Crus-Torres, The Dynamics of Natural Resource Degradation: Rural Households and Women's Strategies for Survival in Northwestern Mexico. Women in International Development, Michigan State University, 2000.

[56] R. A. Giliba, E. K. Boon, C. J. Kayombo, L. I. Chirenje, and E. B. Musamba, "The influence of socio- economic factors on deforestation: a case study of the bereku forest reserve in Tanzania," Journal of Biodiversity, vol. 2, pp. 31-39, 2011. 
[57] G. C. Kajembe, Indigenous Management Systems as a Basis for Community Forestry in Tanzania: A Case Study of Dodoma Urban and Lushoto Districs, Wageningen Agricultural University, 1994. 


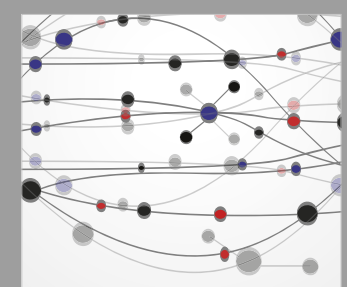

The Scientific World Journal
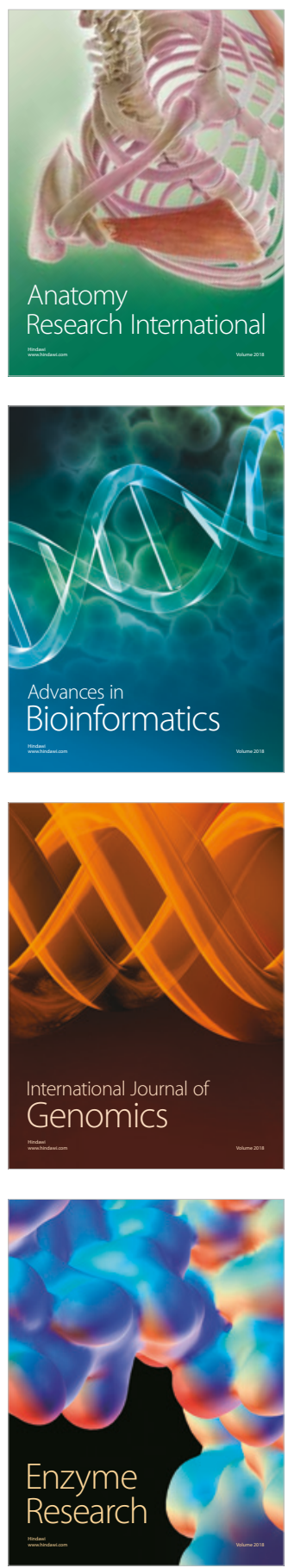
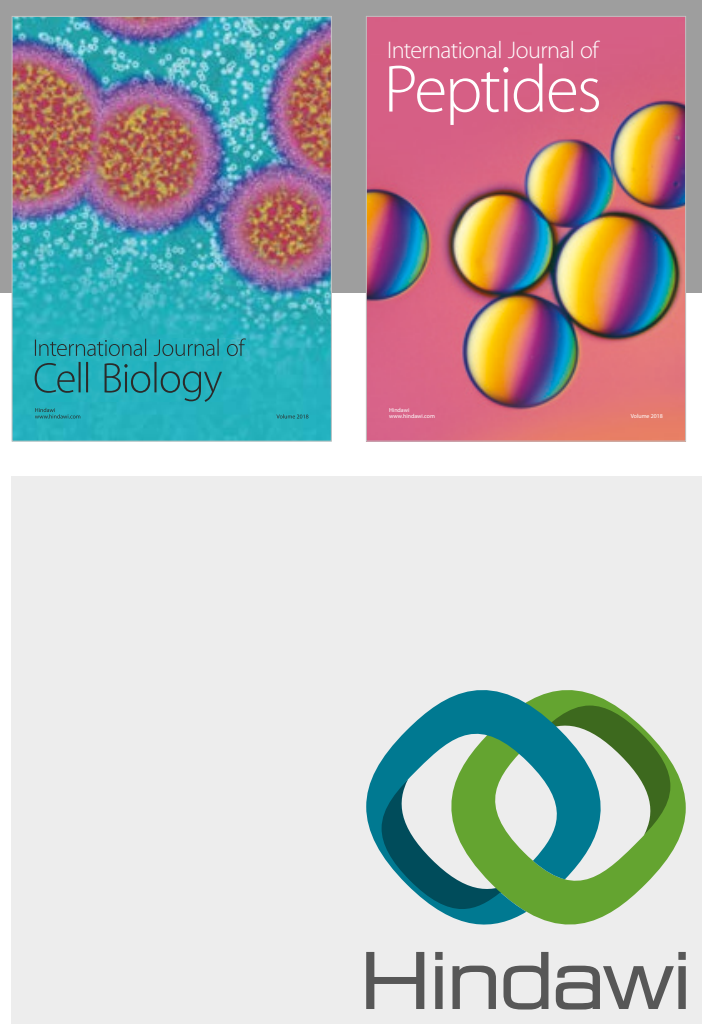

Submit your manuscripts at

www.hindawi.com
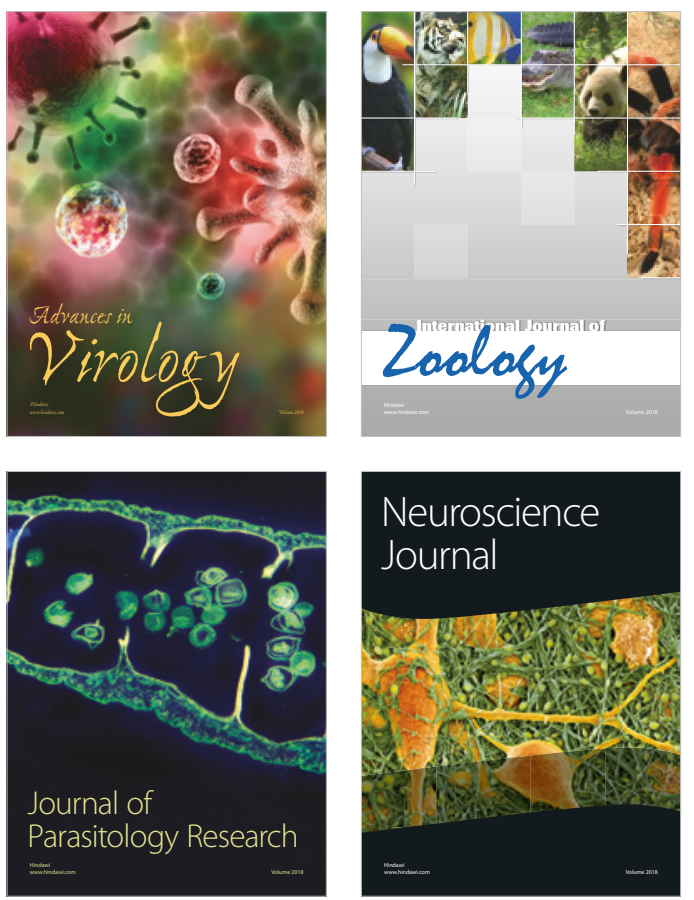
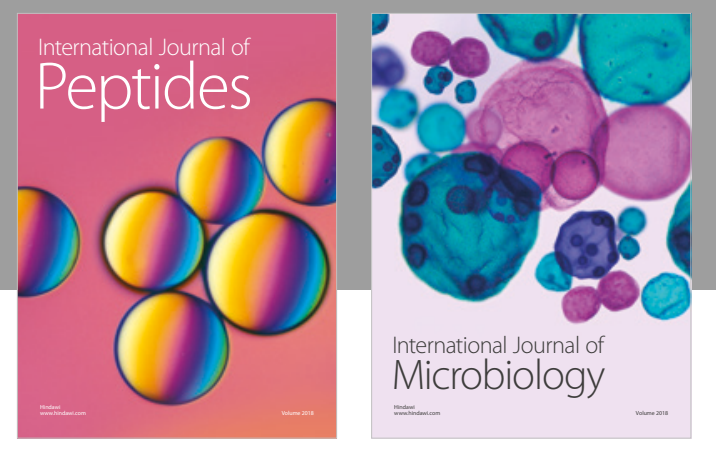

nternational Journal of Microbiology
Journal of
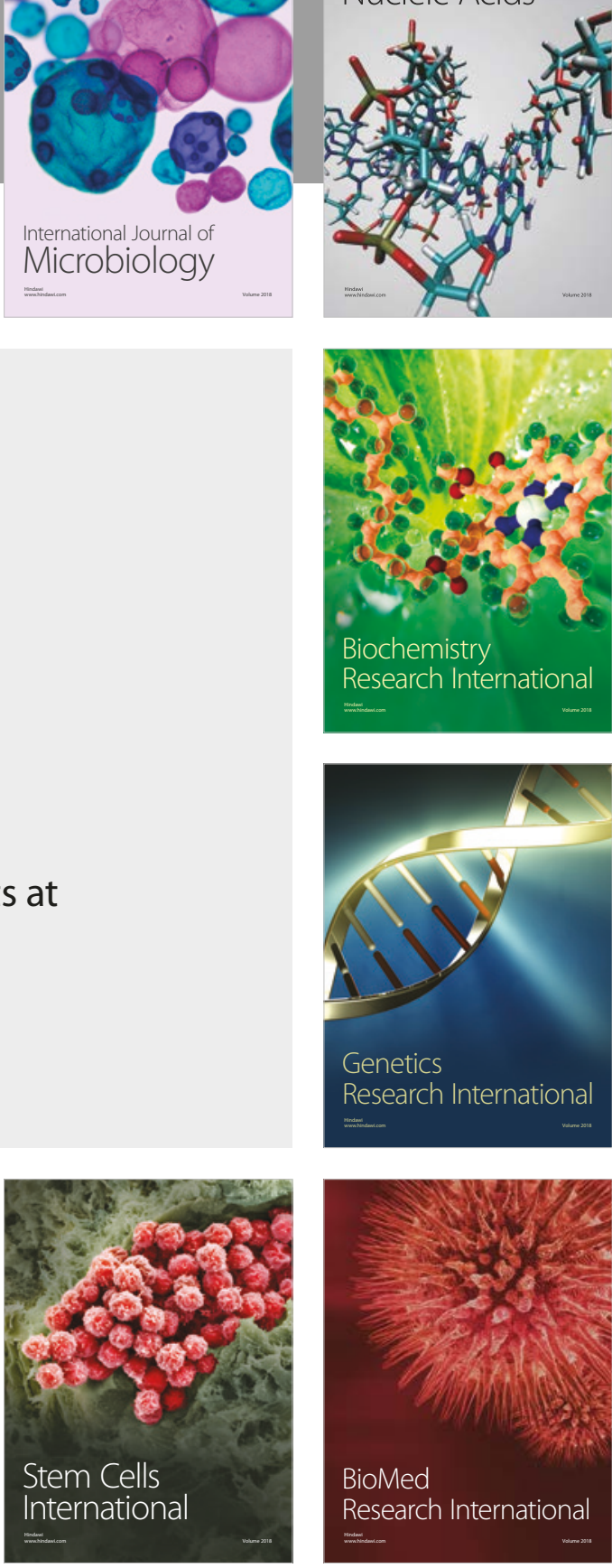
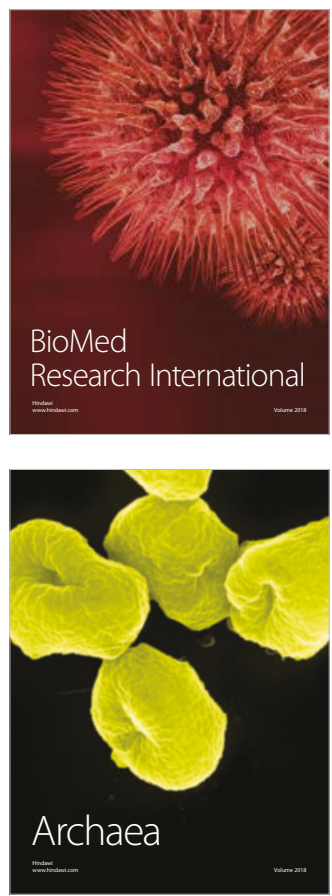